\title{
Perancangan Sistem Hibrid PLTS dan Generator Sebagai Catu Daya Tambahan Pada Tambak Udang Vaname: Studi Kasus Politeknik Kelautan dan Perikanan Kupang
}

\author{
I Made Aditya Nugraha ${ }^{1}$, I Gusti Made Ngurah Desnanjaya ${ }^{2}$, Lukas G. G Serihollo ${ }^{3}$, Jhon Septin M. Siregar ${ }^{4}$ \\ Submission: 09-03-2020, Accepted: 30-06-2020
}

\begin{abstract}
The study discusses the design of hybrid systems between solar power plant, generators and national electric company (PLN) as an additional power supply for the Vaname Shrimp Pond. The use of solar power plant as a form of exploiting the potential of solar energy and maintaining the reliability of electricity in the shrimp pond and a larger area of East Nusa Tenggara. The design is constructed from collecting supporting data, determining the power generated by the solar power plant, and calculating the hybrid system used. This system can provide the energy when experiencing blackouts and if it cloudy. This electricity comes from solar power plant which is able to produce $58.76 \mathrm{kWh} /$ day, 5000 VA generators and PLN of $20 \mathrm{kVA}$.
\end{abstract}

Key word: Hybrid System, Solar Power Plant, Renewable Energy, Vannamei Shrimp pond, Fishery

Intisari - Penelitian membahas tentang rancangan sistem hibrid PLTS dan generator sebagai catu daya tambahan pada tambak Udang Vaname. Penggunaan PLTS sebagai salah satu bentuk pemanfaatan potensi energi matahari yang begitu besar di Nusa Tenggara Timur dan menjaga keandalan listrik di tambak. Perancangan dilakukan dengan cara mengumpulkan data-data pendukung, menetapkan daya yang dihasilkan PLTS, dan menghitung sistem hibrid yang digunakan. Sistem ini dapat memberikan energi ketika mengalami pemadaman listrik dan jika dalam keadaan mendung. Energi listrik ini berasal dari PLTS yang mampu menghasilkan energi listrik $58,76 \mathrm{kWh} / \mathrm{hari}$, generator 5000 VA dan PLN sebesar 20 kVA.

Kata kunci: Sistem hibrid, PLTS, Energi Terbarukan, Tambak Udang Vaname, Perikanan

\section{PENDAHULUAN}

PLTS pada saat ini sedang diminati karena dapat digunakan untuk berbagai keperluan sehari-hari dalam

${ }^{I}$ Dosen Program Studi Mekanisasi Perikanan. Politeknik Kelautan dan Perikanan Kupang. Nusa Tenggara Timur;

made.nugraha@kkp.go.id

${ }^{2}$ Dosen Program Studi Sistem Komputer. STIMIK STIKOM

Indonesia. Denpasar, Bali; ngurah.desnanjaya@stiki-

indonesia.ac.id

${ }^{3}$ Dosen Program Studi Teknik Budidaya Perikanan. Politeknik

Kelautan dan Perikanan Kupang. Nusa Tenggara Timur;

lukas.serihollo@kkp.go.id

${ }^{4}$ Dosen Program Studi Teknik Penangkapan Ikan. Politeknik

Kelautan dan Perikanan Kupang. Nusa Tenggara Timur;

jhon.siregar@kkp.go.id memenuhi kebutuhan energi listrik. Pembangkitan energi listrik memanfaatkan energi dari matahari dan mengkonversinya menjadi energi listrik dengan menggunakan panel surya. Hal ini dapat digunakan sebagai alternatif sumber energi listrik disebabkan karena kebutuhan akan energi listrik terus meningkat setiap tahun [1][2][3][4]. Energi baru dan terbarukan yang sesuai dengan tofografi daerah NTT adalah energi dari sinar matahari. NTT terletak di sekitar daerah ekuator sehingga menyebabkan ketersediaan sinar matahari sepanjang tahun. Energi matahari dapat digunakan sebagai pengganti atau dikombinasikan dengan energi konvensional yang mulai terbatas dan harganya yang cukup mahal [3][4][5]. Potensi energi surya di NTT sebesar $6,74 \mathrm{kWh} / \mathrm{m}^{2}$, menyebabkan NTT berpotensi untuk memanfaatkan energi surya sebagai sumber energi listrik [6]. Energi ini telah banyak digunakan dalam berbagai tempat seperti tempat tinggal, perkantoran, penerangan lampu jalan, pabrik, dan lainnya. Perkembangan ini perlu ditingkatkan dan dikaji lebih lanjut, agar dapat lebih bermanfaat terutama di dunia perikanan [1][3][4][5][7][8].

Penggunaan PLTS dan generator dalam memenuhi kebutuhan energi listrik diharapkan dapat meningkatkan produksi udang [1][8]. Pada perancangan sistem hibrid sebagai catu daya pada tambak Udang Vaname ini dititikberatkan untuk menghidupkan kincir air, penerangan dan catu daya. Studi perencanaan ini dibuat untuk dapat membantu catu daya listrik ramah lingkungan, pemanfaatan energi terbarukan, meningkatkan sanitasi tambak serta mengurangi penggunaan energi fosil yang kurang baik untuk lingkungan [1][4]. Sistem hibrid ini memanfaatkan PLTS sebagai sumber utama (primer) yang dikombinasikan dengan generator sebagai sumber energi cadangan. Penggabungan dua sumber energi ini sejalan dengan kebijakan pemerintah untuk menaikan harga bahan bakar minyak (BBM) dalam negeri yang menyebabkan perubahan perekonomian. Hal ini perlu dilakukan dan dapat digunakan sebagai rekomendasi kepada para pemilik tambak Udang Vaname untuk meminimalkan kesulitan ekonomi yang diakibatkan oleh kenaikan bahan bakar dan tarif listrik [8][9].

Udang Vaname (Litopenaeus vannamei) merupakan salah satu komoditi dalam dunia perikanan yang memiliki nilai ekonomis tinggi [10][11][12][13]. Udang Vaname adalah satu spesies udang unggul yang sejak tahun 2002 mulai dibudidayakan di tambak-tambak di Indonesia [12]. Pada tahun 2017, Udang Vaname merupakan salah satu 10 komuditas utama di perairan umum daratan di Indonesia 
dengan jumlah 51.061.866 kg [14][15]. Permintaan pasar terhadap komoditi Udang Vaname selalu mengalami peningkatan setiap tahunnya. Potensi yang sangat besar tersebut menyebabkan perlu pengembangan sistem yang baik, salah satunya dalam penyediaan energi listrik.

Tambak udang sebagai satu ekosistem perairan buatan dan bersifat tertutup sangat diperlukan perlakuan khusus untuk dapat menstimulasi keseimbangan seluruh ekosistem yang ada pada perairan tersebut. Keseimbangan ini diharapkan dapat menciptakan lingkungan yang aman dan nyaman bagi Udang Vaname seperti pada ekosistem alaminya. Namun pada tambak udang di daerah Indonesia Timur masih sangat terbatas dalam keandalan listrik dan pasokannya sehingga masih jauh dari harapan. Penelitian ini diharapkan dapat memberikan gambaran dalam sistem hibrid PLTS dan generator sebagai catu daya pada tambak Udang Vaname.

\section{PENGELOLAAN TAMBAK UDANG VANAME}

\section{A. Budidaya Udang Vaname}

Dinamika kebutuhan pangan dunia setiap saat selalu mengalami peningkatan sejalan dengan semakin bertambahnya populasi manusia yang hidup. Pada Tahun 2019, jumlah penduduk dunia mencapai 7,7 Miliar jiwa. Angka ini mengalami pertumbuhan sebesar 1,08 \% dari tahun 2018. Berdasarkan regional wilayah, Asia merupakan wilayah dengan jumlah penduduk terbanyak, yaitu 4,6 miliar jiwa [16].

Kesadaran masyarakat tentang pentingnya kesehatan juga telah berkembang dengan mulai beralihnya mengkomsi "red meat" menjadi "white meat". Perubahan selera ini mempengaruhi kebutuhan akan hasil ikan per kapita penduduk. Pada tahun 2019, Kementerian Kelautan dan Perikanan mendapatkan data bahwa konsumsi ikan nasional di 34 provinsi mencapai $55,95 \mathrm{~kg} / \mathrm{kapita} / \mathrm{tahun}$. Data ini melebihi target nasional Tahun 2019 sebesar 54,49 kg/ kapita/ tahun [17]. Selanjutnya pada Tahun 2020, untuk mencapai target konsumsi ikan sebesar 56,39 kg/ kapita/ tahun, KKP merencanakan penyerapan sebesar 7,6 Ton produksi perikanan tangkap dan 4,5 juta ton produksi budidaya hasil perikanan. Dalam upaya peningkatan konsumsi ikan KKP menginisiasi dengan sebuah Program Nasional Gerakan Memasyarakatkan Makan Ikan (GEMARIKAN) yang sifatnya promotif dan dilakukan dalam berbagai kegiatan, antara lain kampanye terbuka, penayangan iklan layanan masyarakat, dan lomba masak serba ikan. Konsumsi ikan ini terdiri dari komoditas ikan air laut, udang dan ikan air tawar yang dikonsimsi oleh penduduk.

Udang Vaname (Litopenaeus vannamei) berasal dari Hawai dan telah banyak dikembangkan di Taiwan, Cina, Thailand dan Vietnam. Di Indonesia, Udang Vaname telah dibudidayakan di Lampung, Jawa Timur, dan Sulawesi Selatan dan memberikan hasil yang mengembirakan. Hal ini menyebabkan udang ini dipilih sebagai salah satu spesies yang diharapkan dapat memacu produksi udang nasional [12][13].

Udang Vaname merupakan komoditas konsumsi perikanan ungulan di pasar global, namum memiliki ketersediaan yang terbatas dan belum mencukupi kebutuhan penduduk. Di seluruh dunia, Amerika merupakan negara dengan pengkomsumsi udang terbanyak, diikuti oleh Uni Eropa dan Jepang. Ekuador, Vietnam, India, Bangladesh dan Indonesia merupakan pengekspor udang terbesar di dunia. Dimana pada Tahun 2018 mencapai 110.000 ton atau senilai 930 juta US dollar [14][15].

Dalam budidaya bioata aquatic di tambak dengan sistem semiintensif, intensif, dan superintensif dibutuhkan sejumlah peralatan untuk pengelolaan air. Pembudidayaan biota akuatik dengan kepadatan tinggi dapat menyebabkan turunnya kualitas air yang lebih cepat. Pergantian air saja tidak dapat mengatasi penurunan kualitas air secara cepat. Terdapat beberapa peralatan penting yang digunakan untuk pengelolaan kualitas air, yaitu [1][9][10][12][13]:

\section{a. Aerator}

Aerator adalah peralatan mekanis yang digunakan untuk meningkatkan pemasukan oksigen ke dalam air. Terdapat dua teknik dasar pada perlakuan aerasi tambak, yaitu sistem dengan percikan air ke atas permukaan (splaser) dan gelembung-gelembung udara yang dilepaskan ke dalam air (bubbler).

Oksigen terlarut pada air tambak untuk budidaya bioata akuatik yang dikelola dengan sistem semiintensif, intensif, dan superintensif harus dipertahankan pada konsentrasi jenuh (5 - 7 ppm). Pada budidaya udang jumlah oksigen yang dibutuhkan oleh udang tergantung pada ukuran, suhu, dan padat penebaran. Untuk budidaya intensif dengan padat penebran 300.000 ekor/ ha, oksigen di perairan tambak harus dipertahankan pada kisaran 5 - 10 ppm.

Berbagai jenis peralatan aerasi dapat digunakan untuk memasok kebutuhan oksigen tersebut, tetapi kincir air adalah alat yang paling cocok jika ditinjau dari laju alih oksigen dan kemudahan pemeliharaan. Jenis aerator yang menggunakan gelembung udara tidak mudah dipelihara terutama jika mengalami kebocoran dan terdapat lubang yang tersumbat lumpur. Jenis aerator Air- $\mathrm{O}_{2}$ sangat efektif untuk mengaduk air, tetapi sering mengangkat lumpur dasar sehingga air menjadi keruh dan alih oksigen dari udara terhambat. Kincir air dapat digerakan oleh tenaga listrik maupun tenaga genset.

Aerator tidak harus dihidupkan terus-menerus, terutama pada awal penebaran. Lama waktu aerator dihidupkan ditentukan oleh kadar oksigen dan kondisi dasar tambak. Untuk membersihkan tambak, pengoperasian aerator pada siang hari bisa dikurangi, sedangkan pada malam hari aerator dibutuhkan untuk menambah kadar oksigen. Jika tidak diperlukan, aerator dapat dimatikan sehingga biaya produksi bisa berkurang.

Aerator sebagai alat pemasok oksigen harus digunakan secara efisien dan tepat. Penggunaan aerator yang tidak benar dapat berdampak pada pengeluaran biaya tanpa hasil. Tabel I adalah pedoman penggunaan aerator pada tambak udang.

TABEL I

PEDOMAN PENGOPERASIAN KINCIR

\begin{tabular}{|c|l|l|}
\hline $\begin{array}{c}\text { Umur } \\
\text { Udang } \\
(\text { Hari })\end{array}$ & \multicolumn{1}{|c|}{ Oksigensisasi } & Pembersihan \\
\hline $1-20$ & $\begin{array}{l}\text { Selama mendung/ hujan dan } \\
\text { setelah tambah air }\end{array}$ & $\begin{array}{l}\text { Malam hari 2 - 6 } \\
\text { jam , tiap hari 2 - 3 } \\
\text { hari }\end{array}$ \\
\hline $20-50$ & Selama mendung/ hujan dan & Malam hari 2-6 \\
\hline
\end{tabular}




\begin{tabular}{|c|l|l|}
\hline & setelah tambah air & $\begin{array}{l}\text { jam, tiap hari 2-3 } \\
\text { hari }\end{array}$ \\
\hline $50-90$ & $\begin{array}{l}\text { Selama mendung/ hujan dan } \\
\text { setelah tambah air }\end{array}$ & $\begin{array}{l}\text { Malam hari 2-6 } \\
\text { jam, tiap hari 2-3 } \\
\text { hari }\end{array}$ \\
\hline $90-150$ & $\begin{array}{l}\text { Terus-menerus, selain ketika } \\
\text { pemberian pakan }\end{array}$ & $\begin{array}{l}\text { Terus-menerus, } \\
\text { selain ketika } \\
\text { pemberian pakan }\end{array}$ \\
\hline
\end{tabular}

\section{b. Pompa Air}

Air merupakan faktor penentu daya dukung pada tambak. Jika mutu air baik, daya dukung tambak juga akan semakin baik. Salah satu cara untuk menjaga mutu air tambak adalah dengan melakukan pergantian air tambak.

Pada tambak intensif dan superintensif yang padat penerbarannya sangat tinggi, frekuensi pergantian airnya ditingkatkan untuk menjaga kualitas air. Sebelum air diganti, kondisi air yang akan dimasukan harus diamati dengan melakukan pengukuran $\mathrm{pH}$, oksigen, kecerahan, salinitas dan kekeruhan. Jika kualitas air yang masuk bagus, pergantian air tidak perlu dilakukan sampai $30 \%$. Bila mengganti air lebih dari $10 \%$, pergantian air dilakukan dengan cara membuang air bawah sekaligus memasukan air. Cara ini dapat mengurangi stres pada biota akuatik dan dapat menghindari fluktuasi parameter kualitas air.

Pergantian air pada tambak dilakukan dengan alat tambahan, yaitu pompa air. Pompa air baik yang digerakan oleh listrik PLN maupun mesin genset diperlukan untuk mengambil air dari laut, sungai, sumur, ataupun dari bak-bak tandon. Pompa air juga dapat digunakan untuk menguras air tambak pada saat pengeringan maupun mempercepat pengeringan air di tambak. Kecepatan pemasukan dan pengeluaran air tergantung pada kekuatan mesin dan besarnya pipa penghisap.

\section{B. Sistem Hibrid}

Energi listrik dibutuhkan dalam budidaya udang, baik kegiatan pembenihan maupun pembesaran. Listrik dibutuhkan untuk pengoperasian aerator, pompa air, penerangan dan sebagainya [1][9][10][13].

Pembangkit listrik tenaga hibrid merupakan suatu sistem pembangkit tenaga listrik yang menggabungkan dua atau lebih pembangkit dengan sumber energi yang berbeda [18][19]. Pada umumnya digunakan untuk isolated grid sehingga didapatkan keuntungan teknis dan ekonomis.

Penggunaan jaringan dengan sistem ini merupakan salah satu bentuk jaringan listrik mikro dengan kapasitas pasokan daya yang relatif kecil. Jaringan ini bekerja pada sistem tegangan rendah dan menengah. Jaringan ini terdiri dari beberapa pembangkit lokal, seperti Pembangkit Tenaga Diesel (PLTD) dan Pembangkit Listrik Tenaga Surya (PLTS). Jaringan ini terhubung dengan jaringan PLN (on-grid) ataupun terpisah dengan jaringan utility (off-grid)[20][21][22]. Jaringan ini mempunyai beberapa komponen sebagai pendukung untuk beroperasi, yaitu terdiri dari Distributed Generation berupa PLTS yang terhubung ke inverter yang kemudian mengisi daya ke baterai [23][24].

a. Pembangkit Listrik Tenaga Surya (PLTS)

I Made Aditya Nugraha : Perancangan Sistem Hibrid PLTS ...
Pembangkit Listrik Tenaga Surya merupakan salah pembangkit dengan memanfaatkan renewable energy yaitu Matahari lalu mengkonversinya menjadi energi listrik. Perubahan energi ini terjadi pada sel-sel photovoltaic di panel surya. Pada sel-sel ini terdapat lapisan-lapisan tipis yang terbuat dari silicon $(\mathrm{Si})$ dan dan bahan semi konduktor lainnya.

Sistem PLTS terdiri dari beberapa komponen, yaitu panel surya, baterai, charge controller, inverter dan kabel instalasi. Komponen-komponen ini akan terpasang pada sistem hibrid.

\section{b. Pembangkit Listrik Tenaga Diesel (PLTD)}

Pembangkit Listrik Tenaga Diesel merupakan salah satu sistem pembangkitan energi listrik yang menggunakan energi fosil. Pembangkitan listrik menggunakan mesin diesel sebagai penggerak mula (prime mover). Prime mover memiliki fungsi untuk menghasilkan tenaga mekanis yang digunakan untuk memutar rotor generator.

\section{METODE PENELITIAN}

Perancangan sistem hibrid dilakukan di Politeknik Kelautan dan Perikanan Kupang dengan mengidentifikasi tambak Udang Langkah-langkah dalam perancangan dengan me-review sistem yang telah ada dan kendala yang sering terjadi. Berikut adalah gambaran perencanaan yang akan dilakukan:

1. Mengumpulkan data-data sebagai pendukung perencanaan sistem hibrid, meliputi data peralatan listrik, data instalasi tambak, data intensitas Matahari, data lingkungan, spesifikasi PLTS yang akan digunakan, data generator, dan data beban terpasang dari PLN.

2. Menetapkan besar daya yang digunakan pada tambak udang Vaname.

3. Menetapkan besar daya yang dihasilkan PLTS

4. Menganalisis sistem hibrid terhadap kebutuhan beban listrik tambak udang.

\section{HASIL DAN PEMBAHASAN}

\section{A. Sistem Kelistrikan Tambak}

Tambak Udang Vaname terletak di Politeknik Kelautan dan Perikanan Kupang dengan jumlah dua buah. Tambak ini digunakan untuk membudidayakan Udang Vaname selama setahun dengan mengalami kurang lebih 3 siklus. Gambar dan spesifikasi tambak dapat dilihat pada Gambar 1 dan Tabel II.

TABEL II

SPESIFIKASI TAMBAK UDANG

\begin{tabular}{|l|l|}
\hline \multicolumn{1}{|c|}{ Keterangan } & \multicolumn{1}{c|}{ Spesifikasi } \\
\hline Jumlah & 2 Buah \\
\hline Ukuran & $8 \mathrm{~m} \times 7 \mathrm{~m} \times 1,5 \mathrm{~m}$ \\
\hline Konstruksi & Beton \\
\hline
\end{tabular}

Dalam sehari konsumsi energi listrik di tambak sebesar $51,72 \mathrm{kWh}$. Beban ini digunakan untuk menghidupkan kincir air, penerangan dan peralatan listrik yang terdapat pada tambak. Penggunaan pompa 1 dan 2 hanya dilakukan pada saat pengisian ulang air di dalam tambak. Tambak disuplai juga dengan listrik yang berasal dari PLN sebesar $22 \mathrm{kVA}$ dan p-ISSN:1693 - 2951; e-ISSN: 2503-2372 
genset sebesar 5000 VA. Tabel III adalah beban listrik pada tambak.

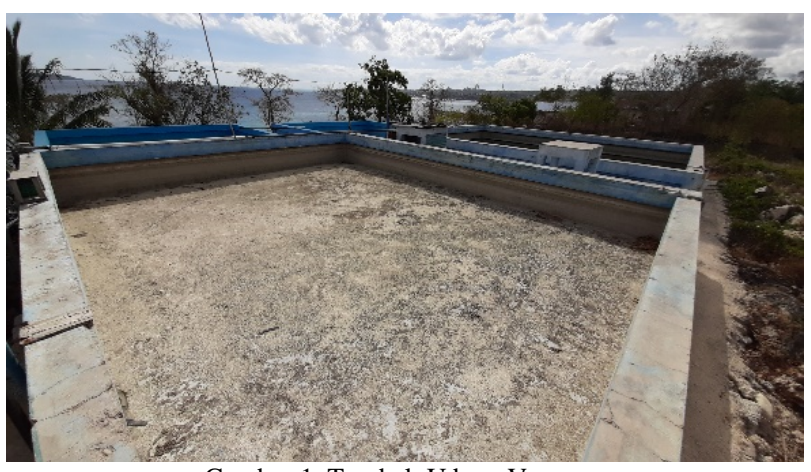

Gambar 1. Tambak Udang Vaname

TABEL III

BEBAN LISTRIK TAMBAK UDANG

\begin{tabular}{|l|l|c|}
\hline \multicolumn{1}{|c|}{ Alat } & \multicolumn{1}{|c|}{ Spesifikasi } & Penggunaan \\
\hline Kincir Air & 6 Buah @ 400 VA / & 24 Jam \\
& AC 220 V & \\
\hline Pompa Air 1 & $11 \mathrm{~kW} \mathrm{(15} \mathrm{HP);} \mathrm{50}$ & Pengisian air di \\
& $\mathrm{Hz} 380 / 660 \quad \mathrm{~V} ;$ & tambak \\
& $21,2 / 12,2 \mathrm{~A}$ & \\
& $3 \mathrm{Phase}$ & \\
\hline Pompa Air 2 & $11 \mathrm{~kW} \mathrm{(15} \mathrm{HP);}$ & Pengisian air di \\
& $50 \mathrm{~Hz} ; 380 / 660 \quad \mathrm{~V} ;$ & tambak \\
& $21,8 / 12,6 \mathrm{~A}$ & \\
\hline Penerangan & $3 \mathrm{Phase}$ & 12 Jam \\
\hline Stop Kontak & 356 VA & 12 Jam \\
\hline Genset & $600 \mathrm{VA}$ & 2istrik Padam \\
\hline PLN & $5000 \mathrm{VA}$ & 24 Jam \\
\hline
\end{tabular}

TABEL IV

PENGUKURAN BEBAN LISTRIK

\begin{tabular}{|c|c|}
\hline Beban & Sub Total Load (A) \\
\hline $\mathrm{R}$ & $31,45 \mathrm{~A}$ \\
\hline $\mathrm{S}$ & $28,28 \mathrm{~A}$ \\
\hline $\mathrm{T}$ & $28,72 \mathrm{~A}$ \\
\hline Total Load & $19.459 \mathrm{VA}$ \\
\hline
\end{tabular}

Kebutuhan beban listrik dengan daya yang terpasang dari PLN sudah mencukupi untuk tambak udang. Hasil pengukuran beban listrik pada Tabel IV, didapatkan total beban listrik pada tambak sebesar 19,459 kVA. Namun jika terjadi pemadaman listrik penggunaan generator saja tidak dapat memenuhi seluruh kebutuhan beban listrik, sehingga dirancang sistem hibrid dengan menggunakan PLTS sebagai sumber energi tambahan.

\section{B. Output Energi Sistem Hibrid Terhadap Kebutuhan Energi}

Dalam menentukan energi yang dihasilkan dari PLTS, maka dilakukan pengukuran kondisi lingkungan di lokasi tambak. Hasil pengukuran diperoleh selama setahun dari bulan Januari - Desember 2019. Tabel V adalah data kondisi lingkungan pada tambak Udang Vaname.

Dari data pada Tabel V dapat dilihat bahwa pada bulan November menghasilkan radiasi matahari terbesar, yaitu 7,46 $\mathrm{kwh} / \mathrm{m}^{2}$, dengan suhu $31,89^{\circ} \mathrm{C}$, kelembaban udara $63,18 \%$, dan kecepatan angin $2,4 \mathrm{~m} / \mathrm{s}$. Sedangkan pada bulan Juni menghasilkan radiasi matahari terkecil, yaitu $4,84 \mathrm{kwh} / \mathrm{m}^{2}$, dengan suhu $27,24^{\circ} \mathrm{C}$, kelembaban udara $69,28 \%$, dan kecepatan angin $5,43 \mathrm{~m} / \mathrm{s}$. Data pengukuran ini kemudian digunakan untuk menghitung potensi energi listrik yang dihasilkan dari PLTS.

TABEL V

KONDISI LINGKUNGAN PADA TAMBAK UDANG VANAME

\begin{tabular}{|l|c|c|c|c|}
\hline Bulan & $\begin{array}{c}\text { Radiasi } \\
\text { Matahari } \\
\left(\mathbf{k W h} / \mathbf{m}^{2)}\right.\end{array}$ & $\begin{array}{c}\text { Suhu } \\
\left.\mathbf{(}^{\mathbf{0}} \mathbf{C}\right)\end{array}$ & $\begin{array}{c}\text { Kelembaban } \\
\text { Udara } \\
\mathbf{( \% )}\end{array}$ & $\begin{array}{c}\text { Kecepatan } \\
\text { Angin } \\
(\mathbf{m} / \mathbf{s})\end{array}$ \\
\hline Januari & 4,99 & 28,29 & 83,69 & 3,68 \\
\hline Februari & 6,69 & 28,38 & 83,00 & 3,09 \\
\hline Maret & 5,79 & 28,48 & 82,80 & 2,80 \\
\hline April & 5,60 & 28,22 & 78,29 & 3,61 \\
\hline Mei & 5,34 & 27,96 & 74,40 & 4,64 \\
\hline Juni & 4,84 & 27,24 & 69,28 & 5,43 \\
\hline Juli & 5,36 & 26,92 & 67,87 & 4,91 \\
\hline Agustus & 6,16 & 27,23 & 66,69 & 4,68 \\
\hline September & 6,63 & 28,01 & 66,89 & 4,33 \\
\hline Oktober & 7,13 & 29,82 & 65,17 & 3,58 \\
\hline November & 7,46 & 31,89 & 63,18 & 2,40 \\
\hline Desember & 6,79 & 31,57 & 68,67 & 1,87 \\
\hline Rata-Rata & 6,07 & 28,67 & 72,50 & 3,75 \\
\hline
\end{tabular}

TABEL VI

SPESIFIKASI PLTS

\begin{tabular}{|l|c|}
\hline \multicolumn{1}{|c|}{ Komponen } & Spesifikasi \\
\hline Panel Surya & \\
\hline Rated Maximum Power (Pmax) & $240 \mathrm{~W}$ \\
\hline Maximum power tolerance & $5 \%$ \\
\hline Voltage at Pmax (Vmp) & $29,78 \mathrm{~V}$ \\
\hline Current at Pmax (Imp) & $8,06 \mathrm{~A}$ \\
\hline Open-Circuit Voltage (Voc) & $37,12 \mathrm{~V}$ \\
\hline Short-Circuit Voltage (Isc) & $8,69 \mathrm{~A}$ \\
\hline NOTC & $47^{\circ} \mathrm{C}$ \\
\hline Maximum System Voltage & $1000 \mathrm{VDC}$ \\
\hline Jumlah & $14 \mathrm{Buah}$ \\
\hline Baterai & \\
\hline I & $250 \mathrm{Ah}$ \\
\hline V & $12 \mathrm{~V}$ \\
\hline Jumlah & $24 \mathrm{Buah}$ \\
\hline Inverter & \\
\hline PV Voltage & $220 \mathrm{VDC}$ \\
\hline PV Current & $50 \mathrm{~A}$ \\
\hline Output Voltage & $230 \mathrm{VAC}$ \\
\hline Output Frekwency & $50 \mathrm{~Hz}$ \\
\hline Bat Voltage & $220 \mathrm{VDC}$ \\
\hline Model & GSA220-15 KVA/ $50 \mathrm{~A}$ \\
\hline
\end{tabular}

PLTS yang akan digunakan merupakan PLTS yang dulunya digunakan untuk memompa air untuk kebutuhan asrama. PLTS saat ini sudah tidak dipergunakan sehingga akan digunakan sebagai catu daya tambahan pada tambak Udang Vaname. PLTS akan dibuat menjadi sistem hibrid dengan sumber listrik yang telah terpasang, yaitu PLN dan genset. Spesifikasi PLTS yang akan digunakan dapat di lihat pada Tabel VI.

Gambar 2 merupakan sistem hibrid yang dirancang menggunakan PLTS dan generator sebagai catu daya tambahan. Sistem hibrid ini memperoleh energi dari PLTS sebesar 58,76 kWh/hari dan generator 5000 VA. Penggunaan 
DOI: https://doi.org/10.24843/MITE.2020.v19i01.P18

sistem hibrid dapat memenuhi kebutuhan energi listrik di tambak sebesar 51,72 kWh.

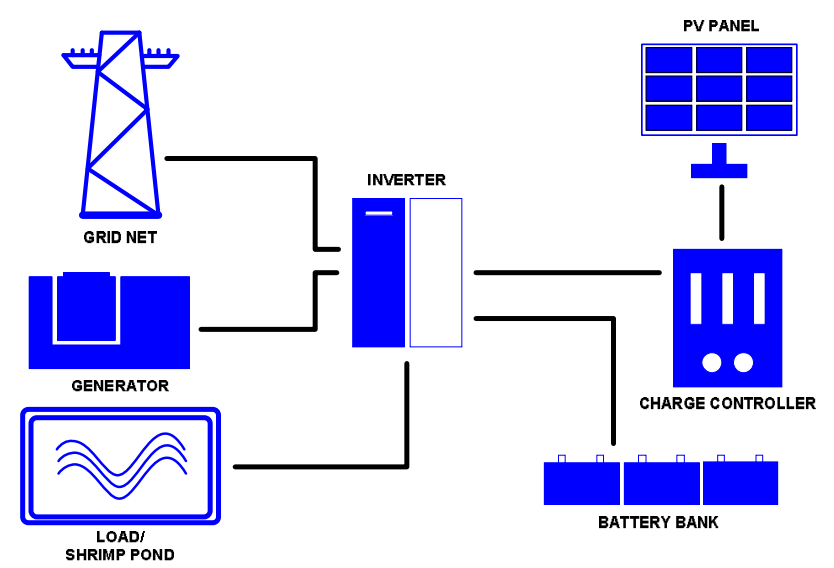

Gambar 2. Skema Penggunaan Energi Listrik Pada Tambak Udang Vaname

\section{KESIMPULAN}

Sistem hibrid PLTS dan generator sebagai catu daya tambahan dapat memenuhi kebutuhan energi listrik di tambak Udang Vaname. Sistem ini dapat memberikan energi listrik ketika mengalami pemadaman listrik dengan menggunakan energi listrik dari PLTS dan generator atau dalam keadaan mendung/hujan dengan menggunakan energi listrik dari PLN. Energi listrik ini berasal dari PLTS yang mampu menghasilkan energi listrik $58,76 \mathrm{kWh} /$ hari, generator 5000 VA dan PLN sebesar $20 \mathrm{kVA}$.

\section{REFERENSI}

[1] A. R. Idris, S. Thaha, S. Tato, "Studi Ekonomis Perencanaan PLTS Stand Alone Untuk Penggerak Motor Kincir Air Pada Tambak Udang,"dalam Prosiding Seminar Hasil Penelitian (SNP2M), 2018, Hal. 61-65.

[2] R. Abdullah dan Subiyanto, "Sistem Hibrida Pembangkit Listrik Energi Terbarukan Terhubung Grid Dengan Kerangka Referansi Natural," JETri, Vol. 16, No.1, p. 1-16, Agustus 2018.

[3] I M. A. Nugraha, P A. R. Ridhana, K. Listuayu, “Optimalisasi Pemasangan Panel Solar Home System Untuk Kehidupan Masyarakat Pedesaan di Ban Kubu Karangasem," Majalah Ilmiah Teknologi Elektro, Vol. 17, No. 1, Hal. 116-123, 2018.

[4] I M. A. Nugraha, P A. R. Ridhana, "Solar Home System Dapat Meningkatkan Kesehatan Masyarakat Desa Ban di Bali,” Bali Health Journal, Vol. 3 No 1, Hal. 21-26, 2019.

[5] E. Damayanti dan M. Iyas, "Rancang Bangun Prototype Sistem Panel ATS Hibrid Antara Turbin Angin dan Solar Sell dengan Grid PLN Untuk Energi Listrik Rumah dengan Daya 456W," TEDC, vol. 12 No.1, Hal. 23 -30, Januari 2018.

[6] Rencana Pengembangan Grid Pulau Kecil Solar PV dan PV Diesel di Provinsi Nusa Tenggara Timur, PT. PLN (Persero) Wil. NTT, 2016.

[7] A. Arimbawa, S. Kumara, R. S. Hartati, "Studi Pemanfaatan Catu Daya Hibrida PLTS 3,7 kWp dan PLN Pada Instalasi Pengolahan Air Limbah Desa Pemecutan Kaja Denpasar Bali," Majalah Ilmiah Teknologi Elektro, Vol. 15, No. 2, Hal. 33-38, Desember 2016.

[8] S. W. Widyanto, S. Wisnugroho, M. Agus, "Pemanfaatan Tenaga Angin Sebagai Pelapis Energi Surya Pada Pembangkit Listrik Tenaga Hibrid di Pulau Wangi-Wangi," dalam Seminar Nasional Sains dan Teknologi 2018, 2018, TE - 013, Hal. 1-12.

[9] V. R. A. Katili, L. Adrianto, Yonvitner, "Evaluasi Emergency Pengembangan Sistem Budidaya Udang Supra Intensif di Kawasan Pesisir Mamboro, Kota Palu Provinsi Sulawesi Tengah," Jurnal

I Made Aditya Nugraha : Perancangan Sistem Hibrid PLTS ...
Pengelolaan Sumberdaya Alam dan Lingkungan, Vol. 7, No. 2, Hal.. 138-147, Agustus 2017.

[10] M. Kordi, H. Ghufran, Jurus Jitu Pengelolaan Tambak Budi Daya Perikanan Ekonomis, Yogyakarta: Andi Offset, 2012

[11] A. Mujiman dan S. R. Suyanto, Budidaya Udang Windu, Jakarta: PT. Penebar Swadaya, 1989

[12] M. Kordi, H. Ghufran, Budi Daya Udang Laut, Yogyakarta: Andi Offset, 2010

[13] M. Kordi, H. Ghufran, Pengelolaan Perikanan Indonesia, Yogyakarta: Pustaka Baru Press, 2015

[14] Shrimp Tails. Stichting Seafood Trade Intelligence Portal (STIP), Shrimp Tails Edition 25, 2019.

[15] Data Ekspor-Impor, Badan Pusat Statistik, 2019.

[16] D. H. Jayani. (2019) Jumlah Penduduk Dunia Pada 2019 Capai 7,7 Miliar Jiwa.[Online]. Available: www.databoks.katadata.co.id

[17] B. Marulitua. (2020) KKP Targetkan Konsumsi Ikan 56,39 kg Pada 2020.[Online]. Available: www.m.trubus.id

[18] G. I. Cahya, Karnoto, dan B. Winardi, "Perancangan Pengatur Suplai Daya Listrik Pada Sistem Hibrid Pembangkit Listrik Tenaga Surya dengan Jala-Jala Listrik PLN," Transient, Vol. 7, No. 2, Juni 2018.

[19] H. Abdillah, A. N. Afandi, I. A. E. Zaeni,"Pemanfaatan Sistem Pembangkit Hibrid dengan Kendali Supply Beban," dalam Prosiding Seminar Nasional Teknologi Elektro Terapan 2018, Vol. 02, No. 01, 2018, Hal. 59 -64.

[20] B. Liputo, Mustofa, Y. Djamalu, E. S. Antu, "Konservasi dan Pemanfaatan Pengelolaan Sistem Pembangkit Listrik Alternatif PLTS, PLTMH di Kecamatan Bulango Ulu Kabupaten Bone Bolango, Gorontalo," Jurnal Abdimas Gorontalo, Vol. 3, Hal. 1-9, 2020.

[21] H. Failasufa, F. D. Wijaya, W. Wilopo, "Analisis Potensi dan Kapasitas Energi Hibrida di Desa Komor Kecamatan Unir Sirau Kabupaten Asmat, Papua," dalam Seminar Nasional Teknologi Fakultas Teknologi Teknik Universitas Krisnadwipayana, Hal. 131138, Juli 2019.

[22] P. G. Chamdareno, H. Hilal, "Analisa Pembangkit Listrik Tenaga Hybrid PLTD-PLTS di Pulau Tunda Serang Banten," Resistor, Vol. 1, No. 1, Hal. 37-44, 2018.

[23] D. A. Panunggul, M. S. Boedoyo, N. A. Sasongko, "Analisa Pemanfaatan Energi Terbarukan di Universitas Pertahanan Sebagai Pendukung Keamanan Pasokan Energi (Studi Kasus: Energi Surya dan Angin)," Jurnal Ketahanan Energi, Vol. 4, No. 2, Hal. 75-91, 2018.

[24] G. T. Setiadanu, A. I. Firmansyah, A. Hadiyono, "Analisis Pembangkit Listrik Untuk Ekonomi Produktif di Pulau Terluar," Ketenagalistrikan dan Energi Terbarukan, Vol. 17, No. 2, Hal. 3546, 2018. 